\section{Gold fever}

WILL the next gold rush take hopeful prospectors to the frozen wastes of Antarctica? K. A Meeker et al. report (Geophys. Res. Lett. 18, 1405-1408; 1991) that the volcano at Mount Erebus, on the Antarctic island of Ross, spews out tiny grains of gold. Particles as large as $20 \mu \mathrm{m}$ have been found at an altitude of $8 \mathrm{~km}$ above the summit, and larger grains have been found in ice a dozen or so kilometres away. Gold emission from volcanoes is fairly well known, but never before has the metal been found in particulate form. Holders of gold bullion need not fear, however - Mount Erebus is putting out only an estimated 60 grams a day, and in windy weather, the authors posit, grains could be dispersed as much as $1,000 \mathrm{~km}$ away from the volcano.

\section{Thereby hangs a tail}

Mrosin is a protein that has given employment to many; it has an active portion (the heads) for biochemists and an inert (structural) element (the rod backbone) for biophysicists. The isolated rod is insoluble in low salt, forming paracrystals with the structural character of the thick filament core of muscle. S. J. Atkinson and M. Stewart (J. Cell Sci. 99, 823-836, 1991) have expressed pieces of the rod in E. coli and find that they form the $\alpha$-helical coiled-coils seen in the native protein. Deletion of the 'skip residues', which interrupt the heptad motif characterizing the coiled-coil, makes no difference to speak of in structure or solubility, but annihilating the C-terminal end generally prevents the formation of insoluble paracrystals. This is also the experience of H. R. Kalbitzer et al. (Biochemistry 30, 8083-8091; 1991), who used NMR to show that the $\mathrm{C}$-terminal residues (nine in one chain of the coiled-coil and twelve in the other) form a freely mobile tail, not part of the rigid rod. They suggest that its function is to pack like cement into the crevices of the filament.

\section{Sesame sauce}

VEgETARIAN food can be dangerous, as evidenced by a case of a young woman who found herself in hospital after tucking into falafel (deep-fried balls of chickpea paste). M. K. Kagi and B. Wuthrich traced the cause of violent nausea, diarrhoea, inflammation and rashies to an allergy provoked not by the falafel itself, but by the sesame seed paste used to make an accompanying white sauce (The Lancet 338, 582; 1991). Screening showed that the $23-$ year-old patient was allergic to sesame seeds in a variety of foods, although potential allergens are usually inactivated by heating - so vegetable oil and baked burger buns are quite safe for sesame sufferers.
MRC, London; C. Auffrey, Paris). Unfortunately, many of the old problems are still with us, despite the introduction of several promising techniques ${ }^{16,17}$ - it is still difficult to find genes in cloned DNA (the Huntington gene, for example) and computers are still learning how to recognize genes in a DNA sequence.

The construction of genetic maps can seem tedious, especially to those who use the fruits of genetics but are not themselves geneticists. Yet without maps there is no genetics. The construction of the human gene map is an essential undertaking for biology and medicine. It is so important that all should have access not only to the maps and their

1. Yoshikawa, A. \& Isono, K. Yeast 6, 383-401 (1990).

2. Levinson, B. et al. Genomics 7, 1-11 (1990).

3. Viskochil, D. et al. Molec. cell. Biol. 11, 906-912 (1991).

4. Derry, J. M. \& Barnard, P. J. HGM 11 Abstr. Cytogenet. Cell Genet. (in the press).

5. Akam, A. Cell 57, 347-349 (1989).

6. Dietz, H. C. et al. Nature 352, 337-339 (1991).

7. Groden, J. et al. Cell 66, 589-600 (1991).

8. Nishisho, I. et al. Science 253, 665-669 (1991).

9. Legouis, R. et al. HGM 11 Abstr. Cytogenet. Cell Genet. (in the press).

10. Palmieri, G. et at. HGM 11 Abstr. Cytogenet. Cell Genet. (in the press). products such as genes and sequences, but also to the process of construction of the maps. As described in the news pages of Nature ${ }^{18}$, there are plans to change the HGM workshops to make them easier to organize and to cope with the exponential increase in both quantity and quality of data. We wish to add our voices to those who argue that whatever format is devised, all should continue to have equal access to the map and its construction. The language of the genome must be universal.

P. N. Goodfellow and L. Sefton are in the Laboratory of Human Molecular Genetics, Imperial Cancer Research Fund, Lincoln's Inn Fields, London WC2A 3PX, UK.

11. Coulson, A., Sulston, J., Brenner, S. \& Karn, J. Proc natn. Acad. Sci. U.S.A. 83, 7821-7825 (1986)

12. Ivens, A. C. et al. HGM 11 Abstr. Cytogenet. Cell Genet. (in the press).

13. Taylor, K., Ulinowski, Z. \& Wolfe, J. HGM 11 Abstr. Cytogenet. Cell Genet. (in the press).

14. Stallings, R. L. et al. Proc. natn. Acad. Sci. U.S.A. 87 6218-6222 (1990)

15. Adams, M. D. et al. Science 252, 1651-1656 (1991) 16. Duyk, G. M., Kim, S., Myers, R. M. \& Cox, D. R. Proc natn. Acad. Sci. U.S.A. 87, 8995-8999 (1990)

17. Buckler, A. J. et al. Proc. natn. Acad. Sci. U.S.A. 88 , 4005-4009 (1991).

18. Gee, H. Nature 352, 747 (1991).

\title{
Polarizing the world of fish
}

\section{Michael F. Land}

WE are especially intrigued by the senses that we lack. Echolocating bats, electrosensitive fish and insects with ultraviolet vision all make us a little envious of ways of apprehending the world that are denied to us. The ability to detect the direction of polarization of light is another such opaque sense, and although it has been known for nearly fifty years that bees use it as a navigational aid, the possibility that our vertebrate relatives might also have this capacity is a more recent idea. The Ways of achieving polarization selectivity. a. Microvillus is intrinsically selective as more molecules are aligned along the structure than across it. This is more obvious in a square section $b$, where twice as many must be aligned paral$|\mathrm{e}|$ to the long axis compared with either orthogonal direction. c, Arrangement of microvilli in a pair of octopus receptors. $d$, Disks in vertebrate receptors are not selective to polarized light from the normal (end-on) direction, but are selective from the side. $e$, In anchovies the lamellae in the cones are stacked vertically with adjacent short and long cones having orthogonal orientations. $f$, Suggestion of Cameron and Pugh ${ }^{1}$ for the sunfish: the cone inner segments act as elliptical wave-guide polarizers, conveying selectivity on the double cones beneath. Open arrows indicate light direction and thin arrows the plane of polarization selectivity. evidence that both birds and fish can discern the pattern of polarization in the surroundings is mounting, and on page 161 of this issue ${ }^{1}$ Cameron and Pugh describe a particularly convincing behavioural demonstration of this capability in the sunfish.

The authors suggest a plausible mechanism for polarization detection, based on the shape and orientation of the double cones of the fish retina. This is important because vertebrate rods and cones are not, in general, organized in a
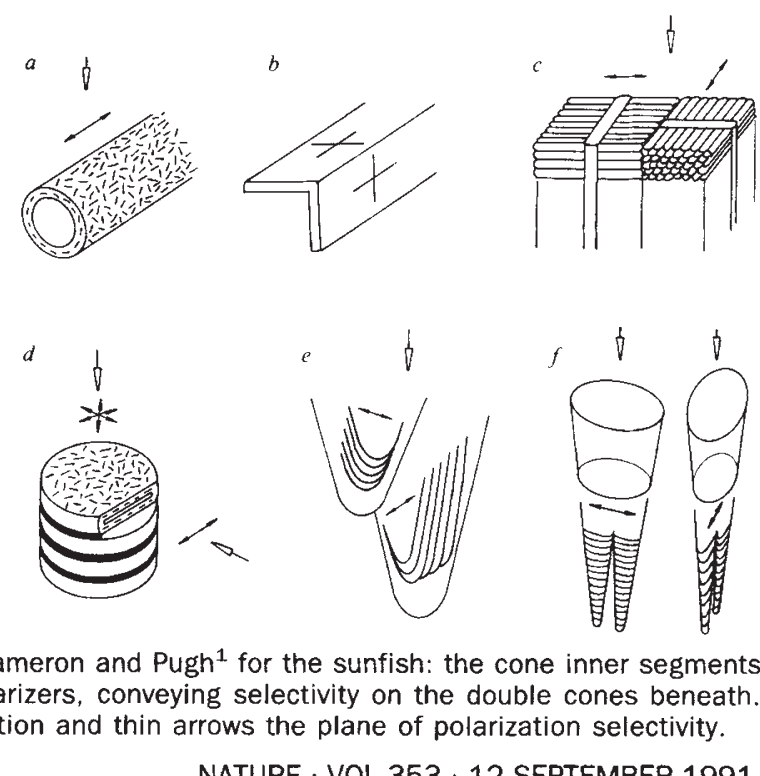